\section{AGGREGATED TECHNICAL AND ECONOMIC INDICATORS AND FACILITIES COEFFICIENT IN THE BUILDING INDUSTRY}

\begin{abstract}
Budgetary indicators, such as technical-economic indicators, are valuation tools commonly used in assessing indicative costs in civil engineering. Their applications are used across the professional construction spectrum, from preparation of the investment process to checking implementation of the construction, in the banking, insurance and property value estimation systems. The catalogues of specific financial indicators may have significant differences between them. These differences can result from different ways of processing the catalogues. As a result of the differences, situations may occur in practice in which a disparity pertains between the values obtained and the effect of the results of planning, implementation, monitoring or other activities related to the buildings.

ABSTRACT
\end{abstract}

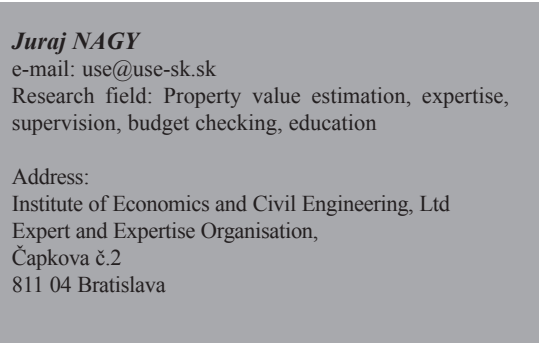

Aggregated financial indicators form the most appropriate tool for creating a cost guide for a building structure, as they fully meet the requirements for characteristics of their content such as:

- clarity and readability

- comparability

- ready and rapid processing

- possibility of mechanical and automatic processing.

At the same time, thanks to their internal structure, which follows the construction and technological stages of the implementation of buildings, they permit an easy orientation and consonance with the visual perception of both the professional and lay public.

As per the requirements of the practice as perceived, when creating the aggregated technical and economic indicators, not only a theoretical contribution to the science, but also a practical application was noted. The conclusions of the theory and application of aggregated TEI (technical and economic indicators) may form the basis for further development of scientific research in economics;

they may be applicable in professional publications and, last but not least, in the educational process.

In order to objectively express the shortcomings and problems arising from the use of resources such as catalogues of indicators, it is necessary to compare and evaluate any differences in the individual procedures. It is believed that any enhanced clarity and simplicity in the adjusted coefficients of financial indicators will be welcomed by all users.

Coefficient $\mathrm{k}_{\mathrm{v}}$, which is the time-frame for price adjustment with the facilities, will also provide the option of an immediate comparison of the investment level of the variants of the construction, the indicative amount of the investment funds required for building construction, and the determination of the volume and type of building structures possible according to the limits of the available funds.

The facilities coefficient is a significant addition to the critical features pertaining to the building structure, particularly with 


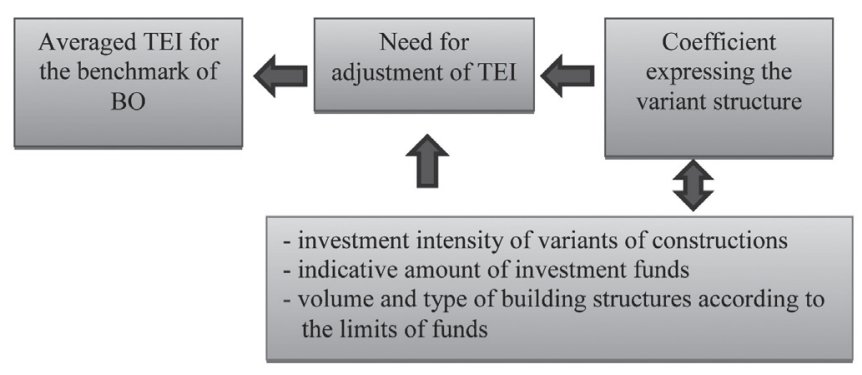

Fig. 1 Diagram expressing the factors of entry requirements for the creation of the $k_{v}$ facilities coefficient. $\quad$ Source: Own processing

regard to the technologies and key materials envisaged (the reason is the current changes in technologies and materials, which are enforcement tools on the market with new prices). The facilities coefficient of the whole building structure contains all of the facilities coefficients of the individual structures.

\section{CALCULATION OF $K_{v}$ FACILITIES COEFFICIENT ACCORDING TO BRADÁČ}

The facilities coefficient of individual construction solutions may be obtained by assigning a final cost to the individual solutions. Then the coefficients are organised in a table in the form of crossconversion factors, as in the literature from Bradáč (7). The principle of creating the table is as follows:

Individual variants are grouped by cost per $€ / \mathrm{m}^{3}$, from the lowest to the highest costs for the construction. The table shows the ratios stated for the individual structures, i.e., $1 / 1$ refers to the ratio of the cost of the variant of an excavation in average geological conditions to the cost of excavations in simple and complex geological conditions. On the diagonal axis, the result is always 1.0 , since the ratio of the numbers to the same number is 1 . Above the diagonal

Tab. 1 Principle of cross-conversion rates.

\begin{tabular}{|c|l|c|c|c|c|}
\hline No. & Earthworks & $\mathbf{€} / \mathbf{m}^{\mathbf{3}}$ & $\mathbf{1}$ & $\mathbf{2}$ & $\mathbf{3}$ \\
\hline 1 & $\begin{array}{l}\text { Excavation in soil, class 1, } \\
\text { with movement of soil } \\
\text { within the site }\end{array}$ & 1.0 & $1 / 2$ & $1 / 3$ \\
\hline 2 & $\begin{array}{l}\text { Excavation in soil, class 3, } \\
\text { with disposal to landfill }\end{array}$ & $\begin{array}{l}\text { Excavation in soil, class 5, } \\
\text { in running water, with } \\
\text { disposal of soil to landfill }\end{array}$ & $2 / 1$ & 1.0 & $2 / 3$ \\
\hline
\end{tabular}

Source: Own processing
Tab. 2 Cross-conversion rates of different versions of excavation works.

\begin{tabular}{|c|l|c|c|c|c|}
\hline No. & Earthworks & $\mathbf{\epsilon} / \mathbf{m}^{\mathbf{3}}$ & $\mathbf{1}$ & $\mathbf{2}$ & $\mathbf{3}$ \\
\hline 1 & $\begin{array}{l}\text { Excavation in soil, class } \\
1, \text { with movement of } \\
\text { soil within the site }\end{array}$ & 519.46 & 1.00 & 0.64 & 0.19 \\
\hline 2 & $\begin{array}{l}\text { Excavation in soil, } \\
\text { class 3, with disposal to } \\
\text { landfill }\end{array}$ & 799.66 & 1.54 & 1.00 & 0.30 \\
\hline 3 & $\begin{array}{l}\text { Excavation in soil, class } \\
5, \text { in running water, } \\
\text { with disposal of soil to } \\
\text { landfill }\end{array}$ & 2635.90 & 5.07 & 3.29 & 1.00 \\
\hline
\end{tabular}

Source: Own processing

are the numbers smaller than 1 , i.e., the shares of cheaper variants compared to the more expensive ( $1 / 2,1 / 3$ etc.). Below the diagonal are the numbers bigger than 1 , i.e., the shares of the more expensive variants compared to the cheaper ones (2/1, 3/1 etc.).

The facilities coefficient thus created can, in practice, be readily and effectively used by multiplying the cost of the construction by the facilities coefficient to obtain the cost of the new construction. This will be sufficient for the work of designers, suppliers and investors; however, it is not enough for the work of experts. The experts in the analytical method of calculating property depreciation must go into the internal structure of the structure and adjust the individual items separately. The coefficient thus created would be a beneficial contribution to experts' work only if they were able to calculate wear and tear by a method other than an analytical one. The sole solution is to create our own $\mathrm{k}_{\mathrm{v}}$ for each individual catalogue of financial indicators.

The average indicators $\mathrm{k}_{\mathrm{v}}=1.0$ of proposed individual aggregated structures pursuant to the categorisation of Nagy are processed at the level of basic budget costs (BBC) in several building categories. The cost data (budgets) in question are adjusted to "standard" conditions (earthworks for class 3 soil, disposal of excess soil up to $5 \mathrm{~km}$, movement of masses within the construction site is calculated in each section up to $1 \mathrm{~km}$ ). As an example, see Table No. 3 for construction - earthworks. In the event that the earthworks are performed on a slightly sloping terrain with movement of the materials to a near-by landfill without additional work, the facilities coefficient will be equal to one.

The standard conditions and performance of work within the construction - stage earthworks in the amount of $20 \mathrm{~m}^{3}$ correspond to the cost of 799.66 EUR. Any simpler (below-standard) conditions pertaining in this example correspond to a cost of 519.46 EUR. More 
2012/2 PAGES $8-12$

Tab. 3 - Budget for earthworks in rock 3.

\begin{tabular}{|c|c|c|c|c|c|c|c|c|}
\hline Order No. & TV & $\mathrm{KCN}$ & Code of item & Description & MU & Total amount & Unit cost & Total cost \\
\hline \multirow[t]{3}{*}{1} & 2 & 3 & 4 & 5 & 6 & 7 & 8 & 9 \\
\hline & $\mathrm{D}$ & & GBP & $\begin{array}{l}\text { Works and deliveries of GBP } \\
\text { (gross building production) }\end{array}$ & & & & 492.70 \\
\hline & $\mathrm{D}$ & & 1 & Earthworks & & & & 492.70 \\
\hline 1 & $\mathrm{~K}$ & 001 & 121101111 & $\begin{array}{l}\text { Removal of topsoil with } \\
\text { horizontal displacement to } \\
\text { piles, within a distance of } \\
100 \mathrm{~m} \text { and up to } 100 \mathrm{~m}^{3}\end{array}$ & $\mathrm{~m}^{3}$ & 20,000 & 1,30 & 25.94 \\
\hline 2 & $\mathrm{~K}$ & 001 & 132201101 & $\begin{array}{l}\text { Excavation of groove } 600 \mathrm{~mm} \\
\text { wide in rock } 3 \text { to } 100 \mathrm{~m}^{3}\end{array}$ & $\mathrm{~m}^{3}$ & 20,000 & 18,21 & 364.12 \\
\hline \multirow[t]{3}{*}{3} & $\mathrm{~K}$ & 001 & 132201109 & $\begin{array}{l}\text { Surcharge to the price because } \\
\text { of hardness of rock } 3\end{array}$ & $\mathrm{~m}^{3}$ & 20,000 & 5,13 & 102.64 \\
\hline & $\mathrm{D}$ & & M & $\begin{array}{l}\text { Works and deliveries of } \\
\text { material }\end{array}$ & & & & 306.96 \\
\hline & $\mathrm{D}$ & & 46-M & $\begin{array}{l}\text { Earthworks for extra assembly } \\
\text { works }\end{array}$ & & & & 306.96 \\
\hline \multirow[t]{2}{*}{4} & $\mathrm{~K}$ & 946 & 4601200611 & $\begin{array}{l}\text { Soil transport including } \\
\text { loading, distribution and } \\
\text { surface adjustment. }\end{array}$ & $\mathrm{m}^{3}$ & 20,000 & 15,35 & 306.96 \\
\hline & & & & Total & & & & 799.66 \\
\hline
\end{tabular}

Source: Processed in Cenkros programme, 2011

complex (above-standard) conditions in this example correspond to a cost of 2635.90 EUR. After calculating the individual standards, we get the facilities coefficient for the applicable conditions of the execution.

Cost $/$ Standard cost $=519.46 / 799.66=0.649=\mathrm{k}_{\mathrm{v}}$

Cost $/$ Standard cost $=2,635.90 / 799.66=3.296=\mathrm{k}_{\mathrm{v}}$
From these results, we may state that the above-standard or below-standard solutions may also be expressed in the final cost of the building by means of coefficients expressing the variants for the individual works of GBP and ABP (associated building production).

The budgetary indicators (BI) are calculated on the basis of data obtained from the budgets of the buildings implemented. The

Tab. 4 - Budget for earthworks in rock 3.

\begin{tabular}{|c|l|l|c|c|c|}
\hline \multirow{2}{*}{ Order No. } & $\begin{array}{c}\text { Data element } \\
\text { name }\end{array}$ & \multicolumn{1}{|c|}{ Variant elements } & \multicolumn{2}{|c|}{ Facilities coefficient } & \multicolumn{2}{|c|}{ Service life/Durability } \\
\cline { 3 - 6 } & $\begin{array}{c}\text { Earthworks and } \\
\text { establishment }\end{array}$ & $\begin{array}{l}\text { simple geology, foundation strip foundation, } \\
\text { reinforced concrete feet, insulation against } \\
\text { ground moisture }\end{array}$ & 1.08 & 1.11 & 150 \\
\hline & $\begin{array}{l}\text { foundation in slopes, reinforcing works, } \\
\text { reinforced concrete ground slabs, insulation } \\
\text { against power water }\end{array}$ & 1.10 & 1.35 & 160 \\
\hline & $\begin{array}{l}\text { difficult geological conditions, soil nail walls, } \\
\text { foundation on piles, complex reinforced } \\
\text { concrete foundations, special insulation }\end{array}$ & 1.21 & 2.55 & 160 & 200 \\
\hline
\end{tabular}

Source: Own processing 
budgets used, including amendments and adjustments according to the actual implementation, are calculated to the cost level by means of the statistical indices of the development of the cost of construction works.

The creation of facilities coefficients $\mathrm{k}_{\mathrm{v}}$ is a back-multiplication of the above-standard or below-standard solutions over the standard that express the variant solution of works described in the aggregate categorisation proposed by Nagy. The adjusted coefficients represent a tool for calculating the indicative cost of building structures for those users of the procedure who lack sufficient experience in the classification of construction works included in budgets, but are also experts within the building industry.

\section{APPLICATION OF FACILITIES COEFFICIENT FOR AN AGGREGATE ITEM}

In a similar way, every aggregate building construction is multiplied by 19. For an easier orientation and valuation system of costing, aggregated items are described in detail for all active and occasional users of the procedures.

\section{CONCLUSION}

The calculation of budgetary indicator items moves between 30 and 50, depending on the type of construction assessed. These

Tab. 5 - Table of indicators for family houses.

\begin{tabular}{|c|c|c|c|}
\hline & NAME OF CONSTRUCTION & Share price & Product description \\
\hline 1 & earthworks and foundation & 8.92 & $\begin{array}{l}\text { earthworks, adjustment of subsoil, wall footing, foots and boards, } \\
\text { waterproofing }\end{array}$ \\
\hline 2 & vertical structures & 15.25 & $\begin{array}{l}\text { from traditional clay brick materials, from assembled prefabricated } \\
\text { systems, monolithic concrete }\end{array}$ \\
\hline 3 & $\begin{array}{l}\text { partitions, partition constructions, } \\
\text { in-fill construction }\end{array}$ & 3.94 & brick to a thickness of $15 \mathrm{~cm}$, plasterboard, wooden \\
\hline 4 & horizontal structures & 12.06 & $\begin{array}{l}\text { reinforced concrete, ceramic, prefabricated, including flat roof } \\
\text { construction }\end{array}$ \\
\hline 5 & supporting structure of staircase & 0.63 & monolithic and prefabricated direct, metal, wooden \\
\hline 6 & roof construction - truss & 6.40 & truss roof construction, thermal insulation to a thickness of $200 \mathrm{~mm}$ \\
\hline 7 & roofing material & 6.05 & $\begin{array}{l}\text { type of roofing material (ceramic, burnt asphalt strips, galvanized } \\
\text { iron), plumbing products from galvanized iron }\end{array}$ \\
\hline 8 & surface working exterior & 4.37 & plaster lime-cement, plastic-silicate plasters (flat roofs) \\
\hline 9 & surface working interior & 6.57 & $\begin{array}{l}\text { smooth lime (lime-cement), stucco plaster, levelling plaster up to } \\
\text { thickness of } 2 \mathrm{~mm}\end{array}$ \\
\hline 10 & surface working of floors & 8.47 & cement screed, PVC \\
\hline 11 & tiling of walls and ceilings & 2.47 & $\begin{array}{l}\text { conventional ceramic tiles, wooden panelling for tongue and groove } \\
\text { made of soft wood }\end{array}$ \\
\hline 12 & filler structures - windows, glass walls & 5.69 & Wooden, made of soft wood and steel profiles \\
\hline 13 & partition structures - door & 4.42 & door made of particle-board with white surface, steel doorframe \\
\hline 14 & sewerage, water and gas fitting & 5.06 & pipeline made of steel, earthenware, PVC, soil attachment glazed \\
\hline 15 & heating systems, excluding heat source & 4.12 & steel pipes, cast iron and tin radiators \\
\hline 16 & $\begin{array}{l}\text { heavy-current wiring installations and } \\
\text { lighting conductor }\end{array}$ & 5.43 & $\begin{array}{l}230 \mathrm{~V} \text { distributions made of copper wires, completion and lighting of } \\
\text { standard type, lighting conductor with galvanized leakage }\end{array}$ \\
\hline 17 & low-voltage distribution & 0.14 & distribution -telephone, TV \\
\hline 18 & transport equipment & & lifts up to $500 \mathrm{~kg}$, cabin painting for metal, PVC facing \\
\hline 19 & special structures & 0.01 & (air-conditioning etc.) \\
\hline
\end{tabular}

Source: Own processing 
budgetary indicators require experts to possess a good knowledge of the creation of budgets and budgetary rules. Experts must know the detailed structure of the classification of structures within the meaning of the classification of building structures and works (CBSW). From previous experience, experts in the "property value estimation" field are sometimes unable to classify individual structures within the meaning of the published catalogue, especially if the structures were divided into several components.
It is expected that the clarity and simplicity afforded by the adjusted coefficients of budgetary indicators will be welcomed by all users. Also, the time-frame for cost adjustments with $\mathrm{k}_{\mathrm{v}}$ will provide the possibility of a rapid comparison of the investment level of variant solutions of the construction, an orientation towards the amount of investment funds needed for the building construction, or securing the volume and type of building constructions to be used within the limits of the funds provided.

\section{REFERENCES}

[1] Púchovský, B.: Technicko - ekonomické ukazovatele, tvorba a využivanie (Technical-economic indicators, their creation and use), In: Slovenské stavebníctvo, 4-5/2003, VIII, pp. 8-9

[2] Nič, M., Majdúch, D., Nagy, J., Gregušová, S., Púchovský, B.: Katalógy rozpočtových ukazovatel'ov a Metodika stanovenia všeobecnej hodnoty nehnutel'ností (Catalogues of budgetary indicators and methodology for determining the general value of property), ÚSZ Bratislava, 2004

[3] Classification of construction works, Guideline of the Ministry of Construction and Regional Development of the Slovak Republic No. 1/2004.

[4] Decree of the Statistical Office of the Slovak Republic No. 323/2010, Statistical Classification of buildings, Coll., June 2010. pp.19, 41

[5] Cenekon: TEU - Technicko-ekonomické ukazovatele (TEI Technical-economic indicators), 1. a 2. part, Bratislava, 1999,

[6] Cenekon: TEU - Technicko-ekonomické ukazovatele (TEI Technical-economic indicators), 1. a 2. part, Bratislava, 2011,
[7] Bradáč, A. : Oceňovanie stavieb nákladovým spôsobom, (Valuation of buildings in a cost way), STU Bratislava, 2005, p.65, ISBN 80-227-1537-9

[8] Nagy, J., Bollová, G., Púchovský, B.: Zborník ukazovatel'ov priemernej rozpočtovej ceny na mernú jednotku objektu, (Proceedings of indicators of average budget cost for unit cost of a building), UNIKA Bratislava, 2006, 89 pp., ISBN 80-88966-54-X

[9] Nagy, J: Kalkulovanie a riadenie nákladov a cien v stavebnom podniku. (Calculation and management of costs and prices in a construction company) In: Zborník z 12. medzinárodnej vedeckej konferencie Q-2010 „Príprava, výstavba a financovanie cestnej dial'ničnej siete“ 29. - 30. 04. 2010, ŽU v Žiline, pp. 95 - 104, ISBN 978-80-970138-4-3, EAN 9788097013943 (Proceedings from 12 international scientific conference Q-2010, Preparation, construction and funding of motorway networks) 